\title{
Fraud Versus Ethics: The Case Of The Backdating Of Stock Options
}

Huldah A. Ryan, Iona College

William Bottiglieri, Iona College

Steven L. Kroleski, Iona College

\begin{abstract}
During the past five years, the Securities and Exchange Commission (SEC) has investigated over 140 companies for their practices of backdating the grant dates of employee stock options (ESOs), and has cited a number of these companies for their part in this behavior that has led to huge financial losses to corporate stockholders. The practice of backdating stock options grant dates is not necessarily illegal, but there may be some ethical issues involved with respect to the firms implicated in the acts. Options backdating may arise, not only because of clerical errors, lax record keeping, or internal control system failure, but also because of the intentional manipulation of corporate reports and documentation. In cases where top executives deliberately manipulate stock options grant dates to further bloat their excessive compensation packages above the amounts that directors approved for them, the firm and its officers/directors may be liable for violations of SEC disclosure requirements, generally accepted accounting principles $(G A A P)$, and tax laws, and if these actions occurred after the passage of the Sarbanes-Oxley Act of 2002, there could be severe penalties imposed on the firm and on the individuals involved.
\end{abstract}

Keywords: Stock options, executive compensation, corporate governance, fraud, ethics.

\section{INTRODUCTION}

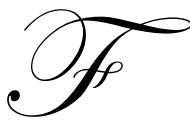

or the past several decades, the U.S. media have bombarded us with stories about corporate executives who try to accumulate as much wealth as possible at the expense of stockholders, by manipulating accounting reports and misrepresenting the results of firm operations under their control. Faced with the choice of self-interest or moral responsibility, the modern-day top manager has allowed greed and avarice to drive his activities and to act in the interest of furthering his own personal goals rather than those of the firm for which he works.

During the past five years, the Securities and Exchange Commission (SEC) has investigated over 140 companies for their practices of backdating the grant dates of employee stock options (ESOs), and has cited a number of these companies for their part in this behavior that has led to huge financial losses to corporate stockholders. The practice of backdating stock options grant dates is not necessarily illegal, but there may be some ethical issues involved with respect to the firms implicated in the acts. Options backdating may arise, not only because of clerical errors, lax record keeping, or internal control system failure, but also because of the intentional manipulation of corporate reports and documentation. In cases where top executives deliberately manipulate stock options grant dates to further bloat their excessive compensation packages above the amounts that directors approved for them, the firm and its officers/directors may be liable for violations of SEC disclosure requirements, generally accepted accounting principles (GAAP), and tax evasion, and if these actions occurred after the passage of the Sarbanes-Oxley Act of 2002, there could be severe penalties imposed on the firm and on the individuals involved.

Previous studies suggest that agency conflicts may arise because of the separation between ownership and management, and because corporate operations and decision making by management may be geared towards 
furthering its own objectives, which may not be in the best interest of the absentee stockholders (Fama and Jensen, 1983; and Jensen and Meckling, 1976). Stock options have become widely used since the second half of the last century when they were originally established as an anti-takeover device, and as a means of aligning the objectives of management and stockholders by linking executive compensation to firm performance. Since then, they have evolved into becoming a major element of non-salary based compensation as a means of attracting and retaining toplevel officers, especially for start-ups and cash strapped companies with limited cash flows.

Stock options by their very nature may encourage corporate executives to 'bend the rules' to increase the value of their compensation, thereby raising possible ethics issues or violations, or to commit outright accounting fraud and misrepresentation. A stock option, which is a financial contract between a firm and an employee, gives the employee the right, but not the obligation to buy an agreed-upon number of shares of stock from the firm, at an agreed-upon price after a specified period of service during which time, it is expected that the firm performance will eventually lead to an increase in the stock price. This agreed-upon price, which is also the exercise price at which the employee would eventually buy the stock, should be no lower than the market price of the stock on the date of the options grant.

The stock options scandals do not only relate to options backdating. They also involve options forwarddating, whereby the executives hold out the filing of the necessary documentation of the grant with the SEC until the stock price has fallen to a low point, and then report the related date as the options date. A major study on stock options backdating by Lie (2005) reveals that stock market movements before and after stock option grants during the 1992-2002 period indicate a pattern of stock options backdating activity. Based on his data, he suggests that if executives did not show adequate transparency in the stock option issuance record process, this was an indication that they were essentially pricing the options on dates when the stock was trading at the lowest point of the period.

This study discusses several theories on ethics and examines the issue of stock options manipulations and the specific violations committed to determine whether the actions by executives were fraudulent or unethical. Specifically, the discussion focuses on issues of ethics and fraud as they relate to stock options backdating, the most prevalent factor in the options mispricing activities.

\section{THEORIES ON ETHICS}

The business literature has highlighted several variables that affect management decision-making, including age, gender, environment, level of cognitive moral development, and organizational culture (the system of moral rules that influence the behavior of management, employees, customers and other stakeholders of the firm). The field of ethics is very wide and encompasses such concepts as morality, personal values, and rules of conduct, norms, principles, and individual behavior. Within the firm setting, the importance of ethics in the decision-making process has become more pronounced, especially during the past decade in light of the many scandals that have plagued the corporate world. We discuss briefly, three of several theories on ethics that have been proposed in the literature. The popular approaches chosen provide a basis for judging individual activities within the organization. They include the concepts of:

- Deontology - This concept may be used to describe the individual's belief of what is right or wrong. Individuals are assumed to be rational beings with the free will to make their own decisions. Deontology proposes that human beings have certain rights to pursue their own self-interests, but the rights of others should be respected in the pursuits (Kant 1959; De George 1990). As it relates to stock options backdating, the deontological approach recognizes that corporate officials will strive to understate expenses and thereby maximize earnings targets from which they will ultimately benefit, but it also deems it to be morally wrong for them to commit unethical or fraudulent acts against stockholders in so doing. This means that one individual would be benefiting at another's expense. The concept could therefore be used as a guide to top executives in their decision-making, that they have a moral duty to act in the interest of the owners of the firm who hired them to manage its daily operations.

- Utilitarianism is a philosophy, which proposes that human behavior follows a "results-based" approach. It evaluates a situation in terms of its costs and benefits, and advocates that an action is justified when the 
benefits outweigh the costs. De George (1990) proposes that a moral decision is one that results in the greatest utility. Human beings are believed to be basically self-gratifying, and in their attempts to maximize their objectives, other individuals may suffer. However, a behavior may be acceptable if individuals can benefit from it. For example, the management may understate compensation expenses, but if this is done in an effort to meet or beat earnings targets, there may be costs involved if the market is informed of this activity, because firm value may ultimately decrease. On the other hand, the benefits realized could include higher stock prices, and, if executive compensation is tied to earnings targets, expenses understatements could lead to increased gains to the management. Therefore, some good may result from the activity.

- Machiavellianism is a viewpoint that deems individuals as being weak and cowardly. It holds that the 'end justifies the means', even if it means exploiting the weak. Individuals will engage in any form of manipulation if it will enhance their own personal goals. In the process of achieving benefits, innocent individuals may get hurt. As this relates to options backdating, stockholders may experience financial losses, but the management's goal of maximizing its perks is being realized.

\section{FRAUD AND BUSINESS}

The issue of fraud is an ongoing problem in business, which can be defined as a deception deliberately designed to secure unlawful gain; and an intentional scheme to mislead that could result in harm to another person. Legal fraud encompasses acts, omissions, or concealments involving breach of equitable or legal duty or trust or confidence.

A common explanation for fraud in business is the pressure on management to report increased earnings each period. Failure to show increased financial performance implies incompetence and could have consequences for the management. Fraud occurs where the conditions are right (a motive, an opportunity, and a justification). A model developed by Loebbecke, Eining and Willingham (1989) proposes a causal framework to assess the likelihood of management fraud. It posits that the probability of management fraud (or material irregularities) is a function of the existing conditions, the degree to which individuals of authority have the motivation to commit fraud, and the degree to which these individuals have an attitude or set of moral values that allow them to commit fraud.

According to the Committee of Sponsoring Organizations of the Treadway Commission (COSO) report (1999), fraud in accounting covers a broad range of activities including:

- $\quad$ improper revenue recognition, i.e. recording fictitious revenue; recording revenue prematurely; and overstating revenue;

- $\quad$ overstating existing assets; recording fictitious assets or assets not owned;

- $\quad$ capitalizing items that should be expensed; and

- $\quad$ understating expenses and liabilities.

\section{MANIPULATIONS OF STOCK OPTIONS}

The increase in the incidences of stock options grant date manipulation was rampant prior to 2002 because firms had up to 45 days after the end of the fiscal year to file the necessary documentation with the SEC. Thus, corporate officials could easily check back on the month when the board agreed on the number of options to be granted, choose the date with the lowest closing stock price as the grant date, and the closing stock price as the exercise price. The ethical issues arise when they fail to communicate this fact to stockholders.

The backdating of grant dates is a major aspect of stock options manipulation, and it enables the senior executive to accumulate additional capital gains and therefore, personal wealth that was entirely independent of firm performance. Narayanan et al. (2007) examine some of the issues associated with options backdating for a sample of firms that were charged with backdating, and report that this activity results in an average loss in firm value of 
about 7\%, which in dollar terms amount to about $\$ 400$ million per firm. At the same time, the average executive could pocket additional compensation of about $\$ 500,000$ per firm annually from stock options backdating.

The backdating issue also means that an executive would have already benefited from the options even before he begins to provide the period of service required. If the date filed with the SEC is at-the-money, then it means that the exercise price is the same as the closing market price of the stock on the grant date. On the other hand, if the date recorded by the executive is different from the date that the board of directors actually granted the option, especially when the stock price is trading at a lower price than the grant date, then the option is recorded inthe-money, and fraudulent issues or ethical issues may arise because the option is not eligible for an expense deduction if executives are paid compensation in excess of $\$ 1$ million.

\section{CIVIL AND CRIMINAL ISSUES}

The firm could be charged with civil fraud if it can be proven that executives engage in schemes to intentionally misrepresent the specifics of the grant. One can argue that if the exercise price is less than the closing price on the grant date, then the firm is discounting the price of the option to executives, and this may be interpreted as a gift and therefore not qualified for expense deduction. The accounting implications and tax penalties involved could then become an issue of fraud, with which the firm would have to deal. The financial blow to the firm could be enormous. A vast amount of the literature focuses on the pressure faced by management to show increased earnings every period and their manipulation of financial accounts to achieve them. Albrecht and Albrecht (2002) reveal that accounting misrepresentations and fraud account for $\$ 600$ billion per year in lost revenue to shareholders. The courts have dealt with the issue of backdating stock options in both a criminal and civil context. The claims in each instance are based on fraud and the violation of securities laws respectively.

\section{Civil Case}

In a June, 2007 decision in a shareholder derivative suit, the U.S. District Court for the Northern District of California wrote:

By now, the story of stock options backdating is familiar. A year ago, a series of articles noted extraordinary returns on stock options granted to officers, directors and employees of some companies. A suspiciously high number of options were ostensibly granted at times where stock prices were at periodic lows followed by sharp increases in price. Such patterns were particularly common in the high-technology sector. These articles noted that the chances of such exquisite timing were slimmer than winning the lottery, and for some company's patterns, much slimmer than winning the lottery several times over. Eventually it was determined that such buy-low-sell-high returns simply could not be the product of chance. In some instances, the grant dates were obviously backdated to maximize returns for the grantees and minimize the compensation expense reported by the company. ${ }^{I}$

In this case, the defendants were current and former officers and directors of Zoran Corporation who were alleged to have received backdated stock options. All defendants were alleged to have issued false statements in financial reports, proxy statements, and other SEC filings with respect to the corporation, and were alleged to have received backdated stock options. The civil complaint alleged claims under the Securities Exchange Act of 1934 in addition to various claims under Delaware State law. The defendants had made a motion to dismiss the complaint as being insufficient under various legal grounds. The court denied this motion.

The familiarity the court referred to in the quoted section above had to do with the prevalence of this backdating. The cited study estimated that $19 \%$ of the so-called at-the-money grants given to top executives between

\footnotetext{
${ }^{1}$ In Re Zoran Corporation Derivative Litigation, United States District Court For The Northern District Of California, 2007 U.S. Dist. Lexis 43402,

referring to Randall A. Heron and Erik Lie, What Fraction of Stock Option Grants Have Been Backdated or Manipulated? (July 14, 2006), available at http://www.issproxy.com/pdf/OptionsBackdatingStudy071406.pdf
} 
1996 and 2005 were backdated or otherwise manipulated. ${ }^{2}$ There is a clear demarcation surrounding the 2002 twoday reporting requirement imposed by the SEC requiring executives to report stock option grants. Prior to this requirement the estimate was that $23 \%$ of unscheduled, at-the-money grants were backdated and that after this requirement was imposed the percentage decreased to $10 \% .^{3}$

The court began its decision with a discussion of the nature of the stock option and the circumstances of its grant. Once the option has vested, its stock prices rise and the options have value; if the stock price falls the options become worthless. The court noted the difference for options recorded "in-the-money" and "at-the-money". Granting an in-the-money option would cause a company to recognize compensation expense in the amount of the difference between the market price and the exercise price while grants of at-the-money options would not require the recognition of any compensation as the company did not forego any revenue by granting them. Thus the motive for backdating options was clear, i.e. to avoid the recognition of compensation expense and the resultant increase in earnings.

This particular proceeding was instituted by the defendant and required the court to test the legal sufficiency of the allegations in the complaint. As such, the court reviewed the alleged facts in light of the applicable law and construed the allegations in the light most favorable to the plaintiff. If the analysis resulted in a conclusion that the complaint was sufficient, the motion by the defendants would be denied. If however, even under this relaxed standard of proof the complaint was deemed insufficient, then the complaint would be dismissed and the matter ended.

The court reviewed the relevant accounting treatment of stock options as enunciated in Accounting Principles Board Opinion No. 25 "Accounting for Stock Issued to Employees" and Financial Accounting Standards Board Principle No. 123. In general the determination as to whether a company must recognize compensation expense for stock options depends on the option price and the stock's market price on the measurement date of the grant. This measurement date is the date on which all of the following three items are known: (1) the number of options; (2) the options' recipients and (3) the option or purchase price. The court recognized that the Office of the Chief Accountant of the SEC has acknowledged that the accounting treatment of stock options leaves open the possibility of innocent error and that not every instance of backdating was wrongful and could have resulted from choosing the wrong measurement date. ${ }^{4}$

With this as a background, the Court then discussed the relevant legal thresholds for the claims of wrongful conduct. With respect to the alleged violation of Section 10 (b) of the Securities and Exchange Act of 1934, based on fraud, Plaintiff must plead:

(1) that defendants made a material misrepresentation or omission;

(2) that the misrepresentation was in connection with the purchase or sale of a security;

(3) that the misrepresentation caused the plaintiff's loss;

(4) that the plaintiff relied on the misrepresentation or omission;

(5) that the defendants acted with scienter; and

(6) that the plaintiff suffered damages. Each of these elements must be pled for each defendant. ${ }^{5}$

In order for any defendant to bear responsibility for a material misstatement or omission, each particular defendant must have had substantial participation or intricate involvement in the preparation of fraudulent statements even though the particular defendant might not have made the actual statement itself. In other words,

\footnotetext{
${ }^{2}$ Randall A. Heron and Erik Lie, What Fraction of Stock Option Grants Have Been Backdated or Manipulated? (July 14, 2006), available at http://www.issproxy.com/pdf/OptionsBackdatingStudy071406.pdf, at p. 2

3 id, at p. 3

${ }^{4}$ In Re Zoran Corporation Derivative Litigation, supra, at p. 28

${ }^{5} \mathrm{Id}$, at p. 49
} 
those who either participate in drafting the allegedly false financial statements and those who are responsible for issuing them could be found to have made a material misstatement under the provisions of the relevant statute. ${ }^{6}$

On the elements of whether the alleged misrepresentation was "in connection with the purchase or sale of a security" or "caused plaintiff loss"7 the court faced an interesting question. Generally a section of a claim would be brought by a plaintiff who buys or sells securities in reliance on a false statement. In this shareholders' derivative action however, the plaintiff is the corporation who is alleged to have suffered a loss. Thus, the plaintiff would have to show that the corporation relied on the alleged misrepresentations of the defendants. The court found that a stock option as a sale of securities is sufficient to fulfill this connection requirement in that it is a grant by the corporation to an employee to reward good performance. ${ }^{8}$ As to the reliance element, the court quoted from the plaintiff's submission that, "because the company provided the shares in exchange for the artificially low prices set by the defendants, it relied on false statements regarding their value and compliance with the plans". 9 Stated another way, the corporation was defrauded by its officers who caused it to sell stock for less than the corporation was entitled to receive for those shares. ${ }^{10}$

Under the requirement of scienter, the plaintiff must prove that the defendants acted with the required state of mind in that they embraced "an intent to deceive, manipulate or defraud". ${ }^{11}$ Conduct which is deliberately reckless would also satisfy this requirement. ${ }^{12}$ Courts have found that required state of mind should be considered when the complaint alleges both false statements and the defendants' close involvement in the preparation of those statements. ${ }^{13}$ The active involvement of individuals who served as Chief Executive Officer and Chief Financial Officer in granting these backdated options lead the court to the conclusion that the defendants had the required state of mind under the statutory scheme.

\section{Criminal Case}

In August, 2007 this same court faced a similar issue of the backdating of stock options in the context of a criminal matter in United States of America vs. Gregory L. Reyes. ${ }^{14}$ Defendant Reyes was accused of understating the expenses of Brocade Communications Systems in his position as Chief Executive Officer. The court again recited the effect of this backdating in that the company avoided compensation expenses by retrospectively pricing stock options. The defendant was alleged to have caused the corporation to make it appear that the options had been granted on a day when the fair market value was much lower than the existing market price on the day when the options were actually granted thus avoiding a charge to income. Reyes was tried on charges of criminal conspiracy, engaging in a scheme to defraud creditors, making false filings with the Securities and Exchange Commission, keeping false books and records, and making false statements to the corporation's accountants. At the conclusion of the prosecutor's case, Reyes made a motion for acquittal claiming that the evidence presented by the government was insufficient to sustain a conviction on any of these counts. In such a motion, the role of the court is not to make findings of fact or draw inferences from proven facts. Rather, the question is whether after viewing the evidence in the light most favorable to the prosecution, could any rational jury have found that the essential elements of the crime were proven beyond a reasonable doubt. ${ }^{15}$

The evidence adduced at trial indicated that the practice of backdating of stock options had existed at the corporation for a significant time. The company had a system in which a chart of historical stock prices was created,

\footnotetext{
${ }^{6}$ Howard v. Everex Sys., Inc., 228 F.3d 1057, 1061 n.5 (9th Cir. 2000)

${ }^{7}$ In Re Zoran Corporation Derivative Litigation, supra, at p. 49

${ }^{8}$ Falkowski v. Imation Corp., 309 F.3d 1123, 1129-30 (9th Cir. 2002)

${ }^{9}$ In Re Zoran Corporation Derivative Litigation, supra, at p. 53

${ }^{10} \mathrm{Id}$, at p. 54

${ }^{11}$ Ernst \& Ernst v. Hochfelder, 425 U.S. 185, 193, 96 S. Ct. 1375, 47 L. Ed. 2d 668 (1976)

${ }^{12}$ In re Silicon Graphics Inc., 183 F.3d at 974

${ }^{13}$ In re Daou Sys., Inc., Sec. Litig., 411 F.3d 1006, 1022-24 (9th Cir. 2005)

${ }^{14}$ United States Of America, Plaintiff, v. Gregory L. Reyes, Defendant.

No. C 06-00556 CRB

${ }^{15} \mathrm{Id}$, at p. 2
} 
favorable historical dates and stock price dates and stock prices were selected, documentation was prepared to make it appear as though options had been granted on the more favorable dates, and then the defendant signed the documentation to cause the corporation to officially grant the options. This testimony was essentially undisputed at trial.

Defendant Reyes challenged the sufficiency of this evidence to sustain a conviction on two grounds. Initially he alleged that the evidence did not establish "materiality" or that the investors were swayed either way by the amounts of the compensation expenses that were omitted from the financial statements. He also claimed that the evidence did not establish that he acted with the requisite criminal intent. These particular charges required that the prosecution show that he acted knowingly, i.e. with an appreciation for the false or misleading character of the corporation's financial records or willfully, i.e. with the purpose of violating a known legal duty and knowing the wrongful nature of his actions. Defendant Reyes further contended that the government had not produced evidence that he understood the accounting consequences of this backdating practice, arguing that he thus could not have acted knowingly, willfully, or with an intent to defraud. Thus, on this motion the court had to determine whether a jury could reasonably find that the misrepresentations regarding the stock options were material and whether the defendant had the requisite criminal intent. The court did not have to resolve these issues but only determine if the evidence was sufficient for the jury to consider them. The court found in the affirmative on both issues and denied defendant Reyes' motion to dismiss the charges.

As to materiality, the courts function was to determine whether the prosecution had shown "a substantial likelihood that the disclosure of the omitted fact would have been viewed by the reasonable investor as having significantly altered the total mix of information made available". ${ }^{16}$ In other words, the proof must show a substantial likelihood that a reasonable shareholder would have considered this information important in deciding whether or not to act. ${ }^{17}$

The significant testimony from both experts and investors indicated that the misrepresented financial information was indeed material. A significant investor testified that the backdating of options was essentially "a giveaway of shares" because the granting of the in-the-money options did not align the interests of shareholders and employees. ${ }^{18}$ A portfolio manager also testified that he did not feel the backdating of options was a common practice and that as an investment professional responsible for managing portfolios he would have wanted to know if companies had been inflating their profits by backdating options. Another expert testified that the subject corporation of which the defendant was a CEO had understated its compensation expense by more than $\$ 173$ million in 2001 and more than $\$ 161$ million in 2002. In each of these years the corporation's financial statements showed profits instead of the losses that would have been reported had the compensation expense been properly recognized. This testimony was deemed sufficient by the court to establish that a jury could reasonably find that the misrepresented information was material.

As to the question of criminal intent, the court likewise found that adequate evidence was adduced for a jury to conclude that the defendant had the requisite state of mind. For the most serious charges faced by the defendant the jury would have to find that he acted knowingly, willfully and with intent to defraud the shareholders of the corporation. ${ }^{19}$ The historical charts which were presented to the defendant tracking the historical prices and market prices of the stock before he approved the grants were significant in permitting a jury to draw an inference that he knew about the retrospective pricing and approved of it. There was also significant evidence that the defendant knew of the effect on compensation expense of the backdating of stock options. Thus, the court found on both the issues of materiality and criminal intent that the evidence was sufficient to permit a jury to reasonably find that the prosecution had met its burden of proving both elements of the crimes charged. Thus, the motion for acquittal by Reyes was denied and he had to defend these charges at the trial which continued.

\footnotetext{
${ }^{16}$ Id, at p. 7, citing Basic Inc. v. Levinson, 485 U.S. 224, 231-32, 108 S. Ct. 978, 99 L. Ed. 2d 194 (1988) (quoting TSC Industries, 426 U.S. at 449)

${ }^{17}$ Id, at p. 7, citing TSC Industries, 426 U.S. at 449

${ }^{18} \mathrm{Id}$, at p. 8

${ }^{19} \mathrm{Id}$, at p. 13
} 
Reyes' trial was the first criminal case to be tried by the courts. He was convicted of defrauding investors, and faces years in prison and millions of dollars in fines if he loses his appeal. In addition, his firm, Brocade Communications Systems Inc. was fined civil penalties of $\$ 7$ million by the SEC.

\section{Legal/Ethical Case}

One other area in which the issue of backdated stock options has been adjudicated concerns the liability of third parties for their participation in such a scheme. In July, 2007 the Appellate Division of the Supreme Court of the State of New York considered the effect of this participation on an attorney who was seeking to resign from the Bar of the State of New York. ${ }^{20}$ The attorney had pleaded guilty to charges of securities fraud in admitting that as a former corporate general counsel he had conspired with senior corporate executives to backdate millions of dollars worth of employee stock option grants and that at that time he knew what he was doing was wrong. The attorney sought the permission of the court to resign from the bar rather than be disbarred, claiming that his actions did not involve the deceit of the public. In finding against the attorney the court noted the defendant admitted actions of fraud, conspiracy to commit fraud, making false statements in annual and quarterly SEC reports, falsifying books and records, and making false statements to auditors. The court found that this conduct was a proper basis for automatic disbarment under the Judiciary Law of the State of New York which provides that the commission of a crime, a necessary element of which is deceipt, misrepresentation, etc. is a basis for automatic disbarment. ${ }^{21}$ Accordingly, the attorney was not permitted to resign as a member of the Bar, and his disbarment was given legal effect as of the date of his formal allocution to these charges.

\section{FIRMS INVESTIGATED BY THE SEC}

Table 1 reports the magnitude of the understatement of expenses for a sample of the firms that were cited by the SEC following its investigations on ethical violation.

Table 1: Sample of Firms Cited with Backdating Violations

\begin{tabular}{ll} 
Firm & Understatement of Compensation Expense \\
\hline Broadcom Corp. & Expenses understated by as much as $\$ 1.5 \mathrm{~B}$ \\
Applied Micro Circuits Corp & Expenses understated by $\$ 200$ million \\
Altera Corp. & $\begin{array}{l}\text { Expenses understated by } \$ 47.6 \text { million } \\
\text { Rambus }\end{array}$ \\
KLA-Tencor Corp & $\begin{array}{l}\text { Expenses understated by } \$ 200 \text { million } \\
\text { Expenses understated by } \$ 400 \text { million. The SEC did not accuse } \\
\text { KLA-Tencor Corporation of fraud. Instead, the company agreed to } \\
\text { refrain from future violations of specific federal securities laws. }\end{array}$ \\
Amkor Technology Inc. & Expenses understated by $\$ 106 \mathrm{M}$ \\
Nvidia Corp & Expenses understated by $\$ 190.2$ million \\
\hline
\end{tabular}

\footnotetext{
${ }^{20}$ In the Matter of Myron F. Olesnyckyj, an attorney and counselor-at-law: Departmental Disciplinary Committee For the First Judicial Department, Petitioner, Myron F. Olesnyckyj, Respondent. M-843, M-1408, Supreme Court Of New York, Appellate Division, First Department, 2007 NY Slip Op 6076; 2007 N.Y. App. Div. LEXIS 8445

${ }^{21}$ Judiciary Law, Section 90(4)(e)
} 


\section{FURTHER ACTIONS TAKEN AS A RESULT OF THE INVESTIGATIONS}

\section{Restatements Of Financial Reports}

The firms cited with fraud and/or ethical violations have been forced to restate their financial reports for the years during which they were charged. This involves the inclusion of additional unreported charges for compensation expense resulting from the stock options granted to top officials. The additional outcomes include a failure to meet SEC required quarterly financial reporting filing deadlines; problems with bondholders for late receipts of financial reports; and potential class action lawsuits from stockholders who may have lost out to the bloated compensations packages taken by top executives.

\section{Repricing Of The Exercise Price}

Where instances of backdating were found, firms have been forced to reprice the options to the existing price on the grant date. The result of this was the removal of the additional benefit of the backdating to firm executives.

\section{Resignations Or Firings Of Top Executives}

If senior officials of firms charged with options backdating are allowed to remain in their positions, this sends a wrong signal to the financial markets that the firm operates in an environment that allows individual misdeeds to go unpunished. Accordingly, many boards of directors have designated internal committees to investigate the offenses, which have led to the resignation or firings of several senior executives in recent years. These actions may be some of the first signals aimed at regaining plummeting stockholders' confidence in the firms. Table 2 reports on the results of actions taken against some of the firms and the top executives cited with accounting misrepresentation by the SEC.

Table 2: Outcomes of SEC Investigations into Backdating of Stock Options

\begin{tabular}{ll}
\multicolumn{1}{c}{ Sample of Firms } & \multicolumn{1}{c}{ Outcomes of Investigations } \\
\hline CNET Networks Inc. & CEO resigned \\
McAfee Inc. & CEO and Chairman, George Samenuk resigned \\
Apple Computer Inc. & Top executives have resigned amid probes \\
Monster Worldwide Inc. & Top executives resigned following internal investigations \\
Comverse Technology Inc. & Former CEO is facing extradition proceedings in Namibia \\
Bed Bath \& Beyond & $\begin{array}{l}\text { Investigated for options misdeeds and although the firm admitted to backdating practices, } \\
\text { the board committee concluded that no one had willfully engaged in misconduct. }\end{array}$ \\
Brooks Automation Inc & Charged with unethical stock option granting practices \\
Hewlett Packard & Received an order of 'cease and desist' from committing future violations from the SEC. \\
\hline
\end{tabular}

\section{DISCUSSION}

This study attempts to examine the circumstances surrounding the backdating of stock options scandal and the implications for improvements in corporate governance and greater transparency in firm disclosures for US firms. One of the requirements of the Sarbanes-Oxley Act (SOX) of 2002 was that firms should file the Form 4 report within 2 business days of the grant date. The implementation of the Act, which is geared towards ethical and governance reforms in corporate organizations, has led to a marked decline in the incidence of options backdating since 2002. In his 2005 study, Lie estimates that the incidence of stock options backdating declined about 6.3\% since 2002, and this may be attributed to the effectiveness of the SOX Act. Despite the actions of Congress, in 
passing the Sarbanes-Oxley Act, and the implementing rules given by the SEC, aimed at increasing the credibility of the firm and improving the accuracy of financial reporting, the full effectiveness of the regulations is still a matter for further investigation. The SEC and federal prosecutors are currently still investigating firms charged with options backdating, and the cases will last for several years. Despite this, the SEC has revealed that the tougher laws have resulted in a reduction of financial fraud, down 6\%, from 30\% to 24\% between the 2005 and 2006 fiscal year.

Firms are in the process of dealing with the negative publicity that resulted from the stock options scandals, and trying to restore their lost reputation for integrity. Major challenges still face the accounting profession as it attempts to provide an environment of compliance, where information reported is a faithful representation of the results of operations during the period of review, and the financial condition of the firm.

Despite the threat of punishment, which could include prison time, the data reveal that, as of 2006, firms were still engaging in activities that are open to inquiry, and can have ethical and/or fraudulent implications for the management. The study identifies several issues and raises a number of questions, some of which may require further investigation over time.

Firstly, backdating of stock options provide initial benefits to top executives even before the start of the service period that is required. These benefits include the cost savings to the executive that are based on the difference between the at-the-money price and the in-the-money price. The additional benefits are realized after the service period is completed and the executive decides to exercise the options. At that time, the dollar value of his capital gains would be based on the difference between the exercise price and the market price. The full effect of the backdating scandal may not be determined for several years, and will require further study.

Secondly, the dates involved in some of the citations issued to the firms under study indicate that executives were still engaging in unethical and/or fraudulent activities relative to stock options backdating after 2002. This raises questions about the effectiveness of the corporate governance procedures in place within the firms. Further study could investigate the structure of the board committees appointed within the firms cited by the SEC to determine if their board compositions are in accordance with the suggested representation of outside or independent directors.

Thirdly, a major shortcoming of the activities of the compensation committees is that, in many cases, they used to simply ratify the stock options report prepared by management, and this raises the question of their effectiveness. It is recommended that these members be held accountable for ensuring that the details of the stock option plans documented in the Form 4 report are correct, and in keeping with the decision by the boards of directors who assign the compensation committees to work out the details of the grants. When boards meet to grant stock options, accurate reports of the meetings should be kept, and these meeting dates should be the same dates as those used in the documentations filed with the SEC.

Fourthly, agency theory proposes that the use of stock options as part of executive compensation will align the objectives of management with those of the firm. The activities by management in stock options backdating clearly indicate that management is still focused on maximizing its own objectives at the expense of stockholders, and therefore, the applicability of agency theory to executive compensation is questionable. Further, the results seem to suggest that executives may even be biding their time and keeping in line until the heat of the accounting scandals wear off and then they may return to business as usual.

Finally, it should be noted that stockholders lose their trust in management when corporate scandals erupt. Stock prices fall and, in turn, firm value. Accordingly, firms may be forced to spend vast amounts of their scarce resources to improve their governance systems in at attempt to restore management trustworthiness with stockholders and firm credibility in the marketplace. Future research could determine whether the proper governance mechanisms have been established in the firms that were cited, and could also investigate the effectiveness of these mechanisms. 


\section{REFERENCES}

1. Albrecht, W.S. and C.C. Albrecht, 2002. Root Out Financial Deception, Journal of Accountancy, 193 (4): 30-34.

2. Brady, F. N., and G.E. Wheeler, 1996. An Empirical Study of Ethical Predispositions, Journal of Business Ethics, 15 (9): 927-940.

3. Committee of Sponsoring Organizations of the Treadway Commission (COSO) (1999). Fraudulent Financial Reporting: 1987-1997, An Analysis of U.S. Public Companies, Gale Group.

4. $\quad$ De George, R.T. 1990. Business Ethics, $3^{\text {rd }}$ Edition, (MacMillan), New York.

5. Fama, E.F. and M.C. Jensen 1980. Agency Problems and Residual Claims, Journal of Law and Economics, 26: 327-349.

6. Granitz, N. and D. Loewy, 2007. Applying Ethical Theories: Interpreting and Responding to Student Plagiarism, Journal of Business Ethics, 72 (3): 293-306.

7. Janis, I.L., and L. Mann, 1977. Decision Making:A Psychological Analysis of Conflict Choice and Commitment, (The Free Press), New York.

8. Jensen, M. and W. Meckling, 1976. Theory of the Firm: Managerial Behavior, Agency Costs, and Ownership Structure, Journal of Financial Economics, 11: 305-360.

9. Jones, S.K., and K.M. Hiltebeitel, 1995. Organizational Influence in the Moral Decision Process of Accountants, Journal of Business Ethics, 14 (6): 417-431.

10. Jones, T.M. 1991. Ethical Decision Making By Indivuduals in Organizations: An Issue Contingent Model, Academy of Management Review, 16 (2): 366-395.

11. Kant, I. 1959. Foundations of the Metaphysics of Morals, (Bobbs-Merrill), New York.

12. Loebbecke, J., M. Eining, and Willingham J. (1989) Auditor's Experience with Material Irregularities: Frequency, Nature, and Detectability. Auditing: A Journal of Practice \& Theory 9, 1-28.

13. Lie, E., 2005. On the Timing of CEO Stock Option Awards, Management Science 51 (5): 802-812.

14. McDevitt, R., C. Giapponi, and C. Tromley, 2007. A Model of Ethical Decision Making Making: The Integration of Process and Content, Journal of Business Ethics, 73: 219-229.

15. McDevitt, R., and J. Van Hise, 2002. Influences in Ethical Dilemmas of Increasing Intensity, Journal of Business Ethics, 40 (3): 261-274.

16. Narayanan, M.P., C. Schipani, and J. Seyhun, 2007. The Economic Impact of Backdating of Executive Stock Options, Michigan Law Review, 105 (8): 1597-1641.

17. Trevino, L.K., and S.A. Youngblood, 1990. Bad Apples in Bad Barrels: A Causal Analysis of Ethical Decision Making Behavior, Journal of Applied Psychology, 75 (4): 378-385.

18. Torbenson, Eric. Knight Ridder Tribune Business News, Washington: August 14, 2007.

19. www.thefreedictionary.com 
NOTES 